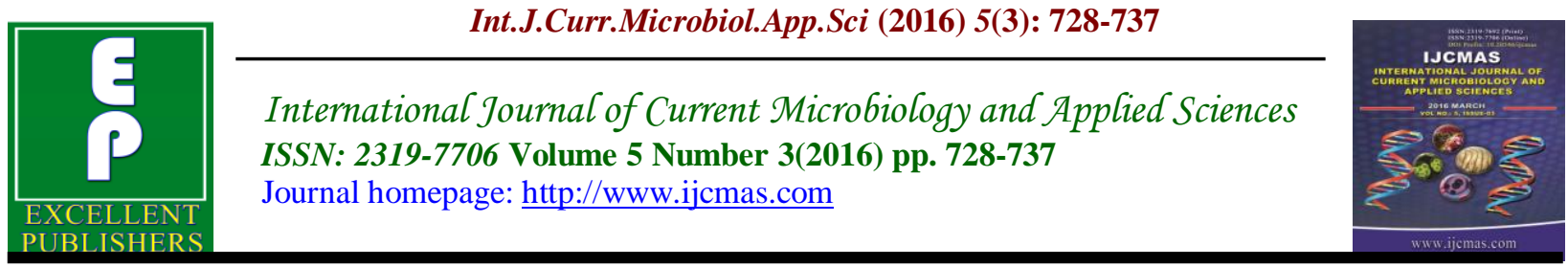

Original Research Article

http://dx.doi.org/10.20546/ijcmas.2016.503.085

\title{
A Lab Originated Bacteriocin and Its Partial Purification and Demonstration of Antimicrobial Activity
}

\author{
Arikta Biswas $^{1}$ and Rajarshi Banerjee ${ }^{2 *}$ \\ ${ }^{1}$ Department of Biological Sciences, Indian Institute of Science Education and Research, \\ Mohanpur, Nadia, West Bengal 741246, India \\ ${ }^{2}$ Department of Biotechnology, Haldia Institute of Technology, Haldia, West Bengal, India \\ *Corresponding author
}

\begin{abstract}
A B S T R A C T
Keywords

Probiotics,

Bacteriocins, Antimicrobial activity, Gastrointestinal pathogens.

Article Info

Accepted:

20 February 2016

Available Online:

10 March 2016

Probiotics help maintain human health using different mechanisms. Recently, several reports have been published which deal with such beneficial action which is said to be obtained by the secretion of Lantibiotics. This study focuses on one Probiotic LAB culture isolated from our local niche. This LAB has revealed certain beneficial effects in aquaculture systems. Fourteen potent gastrointestinal pathogens were subjected to the presence of the probable Lantibiotic. Both qualitative and quantitative estimation of the activities was carried out and the antimicrobial activity was expressed in terms of either growth obtained and/or zone of inhibition in different treatments with the LAB originated bacteriocin. The bacteriocin was subjected to several temperature, $\mathrm{pH}$ and different salt concentration treatments in order to check its stability and efficacy under such conditions. A number of methods were used to concentrate the extract from the activated LAB. Purification was carried out using TLC as well as by adsorptiondesorption method. The results indicate that the bacteriocin can be termed as probable lantibiotic which is quite effective against the gastrointestinal pathogens like Proteus vulgaris and Vibrio parahaemolyticus that have shown to be inhibited by our locally isolated, produced and partially purified LAB originated lantibiotic.
\end{abstract}

\section{Introduction}

Antibiotics don't just kill the bacteria causing illnesses; they also wipe out useful bacteria (called probiotics) that add to a healthy digestive system. A lot of side effects occur due to the antibiotic intake into the body. The side effects are mostly associated with irritation of the mucous membrane of the digestive tract (www.medicalnewstoday.com). Fungal infections of the mouth and digestive tract are very frequent. The greatest risk is found to be of the liver and kidney. Some people are allergic to antibiotics. Some antibiotics decrease the levels of vitamins in the body. Some bacteria are capable of developing resistance to these essential antibiotics. As the lantibiotics are naturally synthesized by probiotics like the lactic acid bacteria, the scope of side effects is less. Since, they are active in very low concentrations only, they 
are not dangerous. These lantibiotics are now used in the food preservatives industry. These should now be targeted as substitutes to the very common antibiotics.

A group of antibacterial proteins termed as bacteriocins are produced by gram-positive bacteria and have shown a narrow to wide antibacterial spectrum against gram-positive bacteria. The antibacterial property is heat stable and it is said that a strain that produces this group of proteins displays a degree of specific self-protection against its own antibacterial peptide. Though, these proteins are quite different from the secretions by gram-negative bacteria, yet usually they also are grouped as bacteriocins (Jack et al., 1995).The antibacterial action against a sensitive cell of a gram-positive strain is produced principally by destabilization of membrane functions. Under certain conditions, gram-negative bacterial cells can also be sensitive to some of these molecules.

Probiotics are organisms or supportive substances that improve intestinal microbial balance, and include Lactobacillus strains, bifidobacteria strains and bioactive proteins such as immunoglobulin $\mathrm{A}$ and lactoferrin (Percival M, 1997). A major consideration in the choice of probiotics is to choose a strain that can survive and establish itself under the conditions encountered in the intestinal environment.

The lantibiotics are a group of ribosomally synthesised, post-translationally modified peptides containing unusual amino acids, such as dehydrated and lanthionine residues. Numerous other lantibiotics have since been identified and can be divided into two groups on the basis of their structures, designated type-A and type-B (Mcauliffe et al., 2001). Lantibiotics primarily act upon Gram-positive bacteria. Their inactivity against Gram-negative bacteria results from their relatively large size which prevents them from penetrating the outer membrane of the Gram-negative cell wall. Posttranslational modifications strongly influence the structure of the peptides as well as their stability against protease degradation (Brötza and Sahlb, 2000). Lantibiotics are grouped into two major categories based on their structural features and differences in their modes of action. Type A lantibiotics are flexible, elongated, amphipathic molecules which act mainly by forming pores in the bacterial cytoplasmic membrane. Type B lantibiotics, on the other hand, have a rigid globular shape and inhibit particular enzymes by forming a complex with their membrane-bound substrates.

The treatment of gastrointestinal infections continues to be complicated due to the expansion of antibiotic resistances (Sanz et al., 2007). The mechanisms of action of probiotics against gastrointestinal pathogens addressed include: (i) modification of the environmental conditions, (ii) competition for nutrients and adhesion sites, (iii) production of antimicrobial metabolites and (iv)modulation of the immune and non immune defense mechanisms of the host.

Though beneficial effects of probiotics have been reported by several scientists and groups for more than 100 years since it was first reported but very few bacteriocins have actually been purified to the extent of being suitably used against gastrointestinal pathogens. Very few bacetriocins like Nisin are commercially used as food preservatives or even in the treatment of gastrointestinal disorder as small molecule antibiotic like peptides.

Over the past few decades several attempts have been made to produce purify and characterize and demonstrate their efficacy as antimicrobial peptides. Several papers have been reported by authors like Svetlana 
et al., 2011; TejpalDhewa, 2012; Sankar, 2013; Tulini, 2011; Sharma and Dadhich, 2014; Alwan et al., 2014; Chakraborty and Bhowal, 2015 and many more.

This study envisages on the stability partial purification and characterization of a local probiotic isolate's produced bacteriocin and demonstration of its antimicrobial activity under several physical stress treatment conditions as well as its activity retention on incurring different concentration / purifications strategies.

\section{Materials and Methods}

\section{Activation and Preparation of Cell Free Extract}

Our own isolate LRSU IV - a Lactobacillus strain isolated and characterized locally in the laboratory (Chandra et al., 2010) and Lactobacillus casei MTCC 1423 was used for this study. The strains were inoculated in the Luria Broth at activated at $28^{\circ} \mathrm{C}$ for 24 hours and henceforth maintained in the same media throughout the study with intermittent transfers onto fresh slants. The individual activated ready to use culture was made cellfree. The CFE was prepared by lysing the cells at $8000 \mathrm{rpm}$ for 5 minutes (Pingitore et al., 2007).

\section{Treatment of CFE with Pathogens}

The CFE from two sets of both the activated cultures was treated with the potent gastrointestinal pathogens for the zone of inhibition test using the agar-diffusion assay. Luria agar plated were seeded with the respective pathogenic strain; in which wells were bored into agar plates by cork-borers and microbial suspensions of $60 \mu \mathrm{L}$ were allowed to diffuse with 10 of the CFE overnight at $37^{\circ} \mathrm{C}$ (Tagg and Mcgiven, 1971). Post incubation the diameter of the zones of inhibition was measured.

The efficacy of the bacteriocin was compared with the zones of inhibition as exhibited by a standard antibiotic i.e. Ciprofloxacin (Data not shown).

\section{Temperature Assay}

The LAB cultures were activated and the $\mathrm{CFE}$ were incubated over night at different temperatures- $28^{\circ} \mathrm{C}, 37^{\circ} \mathrm{C}, 45^{\circ} \mathrm{C}$ and at room temperature. The CFE was then subjected to antimicrobial activity against the test pathogens.

\section{pH Assay}

The CFE was treated at $\mathrm{pH} 3,4,5,6,7,8,9$ using $1 \mathrm{M} \mathrm{HCl}$ or $1 \mathrm{M} \mathrm{NaOH}$. The treated samples were kept overnight at $28^{\circ} \mathrm{C}$ and their antimicrobial activity was tested.

\section{Salt Concentration Assay}

\section{Concentration of the CFE Assay}

The CFE was treated with different volumes of the following salt solutions of $\mathrm{NaCl}$, $\mathrm{MgCl} 2, \mathrm{FeCl}_{3}$ and $\mathrm{ZnCl}_{2}$, at varying concentrations ranging from $50 \mathrm{mM}$ $1000 \mathrm{mM}$ (at an interval of $50 \mathrm{mM}$ ). The samples were subjected to the MIC assay after incubation of the samples overnight at $28^{\circ} \mathrm{C}$.

\section{Concentration of the CFE}

$1 \mathrm{ml}$ of the CFE was taken in two sets of eppendorf tubes and each set was set overnight at $50^{\circ} \mathrm{C}$ and $100^{\circ} \mathrm{C}$. The concentrated bacteriocins when obtained were refrigerated. The next day, this prepared sample was used in the agardiffusion test method. 


\section{Precipitation of the CFE by Acetone Precipitation Method}

$3 \mathrm{ml}$ of the CFE was taken and $12 \mathrm{ml}$ chilled acetone was added. The eppendorf tubes were kept overnight at $0^{0} \mathrm{C}$ and centrifuged at $4^{0} \mathrm{C}$. The supernatant was discarded, evaporated and pellet was re-suspended in $500 \mu 1$ autoclaved water. The antimicrobial activity of the samples was then checked.

\section{Precipitation of the CFE by Adsorption- Desorption Method}

$5 \mathrm{ml}$ of the probiotic cultures (LRSU IV and MTCC 1423) were heated at $70^{\circ} \mathrm{C}$ for 25 minutes to inactivate the microorganisms. The $\mathrm{pH}$ of the culture was adjusted to $\mathrm{pH} 7.0$ with $5 \mathrm{M} \mathrm{NaOH}$ to allow bacteriocin adsorption to the bacterial cells (Pingitore $e t$ al., 2007). The cells were collected by centrifugation, washed twice with $5 \mathrm{mM}$ sodium phosphate buffer ( $\mathrm{pH}$ 7), resuspended in $0.1 \mathrm{M} \mathrm{NaCl}$ solution $(\mathrm{pH} 2.0$, adjusted with $\mathrm{HCl}$ ) to 40 times the original volume of the culture, and agitated at $4^{\circ} \mathrm{Cfor}$ $1 \mathrm{~h}$ to release the bacteriocin molecules from the cell surface. The cells were separated by centrifugation $\left(8000 \mathrm{rpm} 5 \mathrm{~min}\right.$ at $\left.4^{\circ} \mathrm{C}\right)$ and the samples were subjected to the zone of inhibition assays.

\section{Purification of Lantibiotics by Thin Layer Chromatography}

Thin Layer Chromatography was performed on glass slides which was cast with $40 \%$ silica gel. In the analytical experiments, CFE $(30 \mu 1)$ was loaded and subjected the glass slides to two solvent systems- the first being the butanol-acetic acid-water(40:10:20) (Dieuleveux et al., 1998) and the second one being diethyl ether-toluene-ethanol-acetic acid(40:50:2: 0.2) (Pascual et al., 2008). In the preparative slides, the CFE was pooled and loaded onto the glass slides and put them in the more efficient solvent system. If spots were obtained, the spot was eluted and anti-microbial assays were performed.

All the experiments were performed in triplicates and repeated thrice as independent experimental setups. The results shown are the means of the individual observations.

\section{Results and Discussion}

It was already established in our laboratory that the probiotic cultures that we are working with show effectivity in aquacultures (Chandra et al., 2010).

It has been reported by several authors that Lactobacillus species produce bacteriocins (Ahmed et al., 2010;Barefoot and Klaenhammer, 1983; Deraz et al., 2005;Kim and Gilliland, 1993; Leer et al., 1995; Muriana and Klaenhammer, 1991; Noonpakdee et al., 2009; Ogunbanwo et al., 2003; Rajaram et al., 2010; Riaz et al., 2010; Von Mollendorff et al., 2009; Vuyst and Leroy, 2007). In this study, a bacteriocin was produced by LRSU IV (isolated and characterized) was found to inhibit both Gram positive and Gram negative bacteria.

\section{The zone of Inhibition Test}

The agar plates with the CFE in the wells and spread with the pathogens showed prominent zones of inhibition when incubated overnight at $37^{\circ} \mathrm{C}$. The best results were observed for Proteus vulgaris, Vibrio cholerae and Vibrio parahaemolyticus. It was also seen that the LRSU IV strains had enhanced result than the MTCC 1423 counterparts. Thus, the laboratory produced bacteriocins have a more profound effect than the reported strains of bacteriocin producer(s). Since the bacteria Enterobacter aerogenes, Bacillus subtilis, Serratia 
marcesens and Bacillus cereus did not show much significant inhibition zone these bacteria were excluded from further studies.

\section{Temperature Assay}

The antimicrobial tests performed with CFEs of the LRSU IV cultures at room temperature, $28^{0} \mathrm{C}$ and $37^{\circ} \mathrm{C}$ showed significant zones of inhibition at all the three temperatures. But, when compared individually, it was seen that Proteus vulgaris was most inhibited with $\mathrm{CFE}$ treated at $37^{\circ} \mathrm{C}$, while Vibrio cholerae showed better results with $\mathrm{CFE}$ treatment at $28^{\circ} \mathrm{C}$. However, sample at $28^{\circ} \mathrm{C}$ showed an overall better result than samples at other temperatures. In this assay too, the bacteriocin we obtained showed a similar result with the available MTCC1423 bacteriocin.

\section{pH Assay}

The bacteriocin of LRSU IV was stable over a wide $\mathrm{pH}$ range, which is common feature of many bacteriocins (Ivanova et al., 2000).

Table.1 Comparison of Inhibition Pattern of LRSU with Metal Salts at Different Concentrations

\begin{tabular}{|c|c|c|c|c|c|}
\hline Test Organism & $\mathrm{FeCl}_{2}$ & $\mathrm{ZnCl}_{2}$ & $\mathrm{KCl}$ & $\mathrm{NaCl}$ & $\mathrm{MgCl}_{2}$ \\
\hline Vibrio cholerae & $\begin{array}{l}\text { No Growth } \\
\geq 150 \mathrm{mM}\end{array}$ & $\begin{array}{l}\text { No Growth } \\
\geq 350 \mathrm{mM}\end{array}$ & $\begin{array}{l}\text { No Inhibition } \\
\approx 1000 \mathrm{mM}\end{array}$ & $\begin{array}{l}\text { No Inhibition } \\
\approx 1000 \mathrm{mM}\end{array}$ & $\begin{array}{l}\text { No Growth } \\
\geq 350 \mathrm{mM}\end{array}$ \\
\hline $\begin{array}{l}\text { Vibrio } \\
\text { parahaemolyticus }\end{array}$ & $\begin{array}{l}\text { No Growth } \\
\geq 150 \mathrm{mM}\end{array}$ & $\begin{array}{l}\text { No Inhibition } \\
\approx 1000 \mathrm{mM}\end{array}$ & $\begin{array}{l}\text { No Growth } \\
\geq 250 \mathrm{mM}\end{array}$ & $\begin{array}{l}\text { No Growth } \\
\geq 250 \mathrm{mM}\end{array}$ & $\begin{array}{l}\text { No Growth } \\
\geq 150 \mathrm{mM}\end{array}$ \\
\hline Shigelladysenteriae & $\begin{array}{l}\text { No Growth } \\
\geq 350 \mathrm{mM}\end{array}$ & $\begin{array}{l}\text { No Inhibition } \\
\approx 1000 \mathrm{mM}\end{array}$ & $\begin{array}{l}\text { No Growth } \geq \\
500 \mathrm{mM}\end{array}$ & $\begin{array}{l}\text { No Inhibition } \\
\approx 1000 \mathrm{mM}\end{array}$ & $\begin{array}{l}\text { No Growth } \\
\geq 450 \mathrm{mM}\end{array}$ \\
\hline Proteus vulgaris & $\begin{array}{l}\text { No Growth } \\
\geq 100 \mathrm{mM}\end{array}$ & $\begin{array}{l}\text { No Inhibition } \\
\approx 1000 \mathrm{mM}\end{array}$ & $\begin{array}{l}\text { No Inhibition } \\
\approx 1000 \mathrm{mM}\end{array}$ & $\begin{array}{l}\text { No Inhibition } \\
\approx 1000 \mathrm{mM}\end{array}$ & $\begin{array}{l}\text { No Growth } \\
\geq 250 \mathrm{mM}\end{array}$ \\
\hline Salmonella infantis & $\begin{array}{l}\text { No Growth } \\
\geq 100 \mathrm{mM}\end{array}$ & $\begin{array}{l}\text { No Growth } \\
\geq 450 \mathrm{mM}\end{array}$ & $\begin{array}{l}\text { No Growth } \\
\geq 300 \mathrm{mM}\end{array}$ & $\begin{array}{l}\text { No Growth } \\
\geq 800 \mathrm{mM}\end{array}$ & $\begin{array}{l}\text { No Growth } \\
\geq 100 \mathrm{mM} \\
\end{array}$ \\
\hline $\begin{array}{l}\text { Streptococcus } \\
\text { pyogenes }\end{array}$ & $\begin{array}{l}\text { No Inhibition } \\
\approx 1000 \mathrm{mM}\end{array}$ & $\begin{array}{l}\text { No Inhibition } \\
\approx 1000 \mathrm{mM}\end{array}$ & $\begin{array}{l}\text { No Inhibition } \\
\approx 1000 \mathrm{mM}\end{array}$ & $\begin{array}{l}\text { No Inhibition } \\
\approx 1000 \mathrm{mM}\end{array}$ & $\begin{array}{l}\text { No Inhibition } \\
\approx 1000 \mathrm{mM}\end{array}$ \\
\hline $\begin{array}{l}\text { Pseudomonas } \\
\text { aeruginosa }\end{array}$ & $\begin{array}{l}\text { No Growth } \\
\geq 500 \mathrm{mM}\end{array}$ & $\begin{array}{l}\text { No Growth } \\
\geq 450 \mathrm{mM}\end{array}$ & $\begin{array}{l}\text { No Inhibition } \\
\approx 1000 \mathrm{mM}\end{array}$ & $\begin{array}{l}\text { No Inhibition } \\
\approx 1000 \mathrm{mM} \\
\end{array}$ & $\begin{array}{l}\text { No Growth } \\
\geq 600 \mathrm{mM} \\
\end{array}$ \\
\hline $\begin{array}{l}\text { Pseudomonas } \\
\text { fluorescens }\end{array}$ & $\begin{array}{l}\text { No Growth } \\
\geq 500 \mathrm{mM} \\
\end{array}$ & $\begin{array}{l}\text { No Growth } \\
\geq 450 \mathrm{mM}\end{array}$ & $\begin{array}{l}\text { No Inhibition } \\
\approx 1000 \mathrm{mM} \\
\end{array}$ & $\begin{array}{l}\text { No Inhibition } \\
\approx 1000 \mathrm{mM} \\
\end{array}$ & $\begin{array}{l}\text { No Growth } \\
\geq 600 \mathrm{mM}\end{array}$ \\
\hline $\begin{array}{l}\text { Staphylococcus } \\
\text { aureus }\end{array}$ & $\begin{array}{l}\text { No Growth } \\
\geq 500 \mathrm{mM}\end{array}$ & $\begin{array}{l}\text { No Growth } \\
\geq 450 \mathrm{mM}\end{array}$ & $\begin{array}{l}\text { No Growth } \\
\geq 250 \mathrm{mM}\end{array}$ & $\begin{array}{l}\text { No Growth } \\
\geq 700 \mathrm{mM}\end{array}$ & $\begin{array}{l}\text { No Growth } \\
\geq 350 \mathrm{mM}\end{array}$ \\
\hline Klebsiellapneumoniae & $\begin{array}{l}\text { No Growth } \\
\geq 500 \mathrm{mM}\end{array}$ & $\begin{array}{l}\text { No Growth } \\
\geq 400 \mathrm{mM}\end{array}$ & $\begin{array}{l}\text { No Growth } \\
\geq 850 \mathrm{mM}\end{array}$ & $\begin{array}{l}\text { No Growth } \\
\geq 800 \mathrm{mM}\end{array}$ & $\begin{array}{l}\text { No Growth } \\
\geq 500 \mathrm{mM}\end{array}$ \\
\hline
\end{tabular}


Figure.1 Inhibition Pattern of CFE of Isolate (LRSU IV) and MTCC 1423 against Different Potential Pathogens

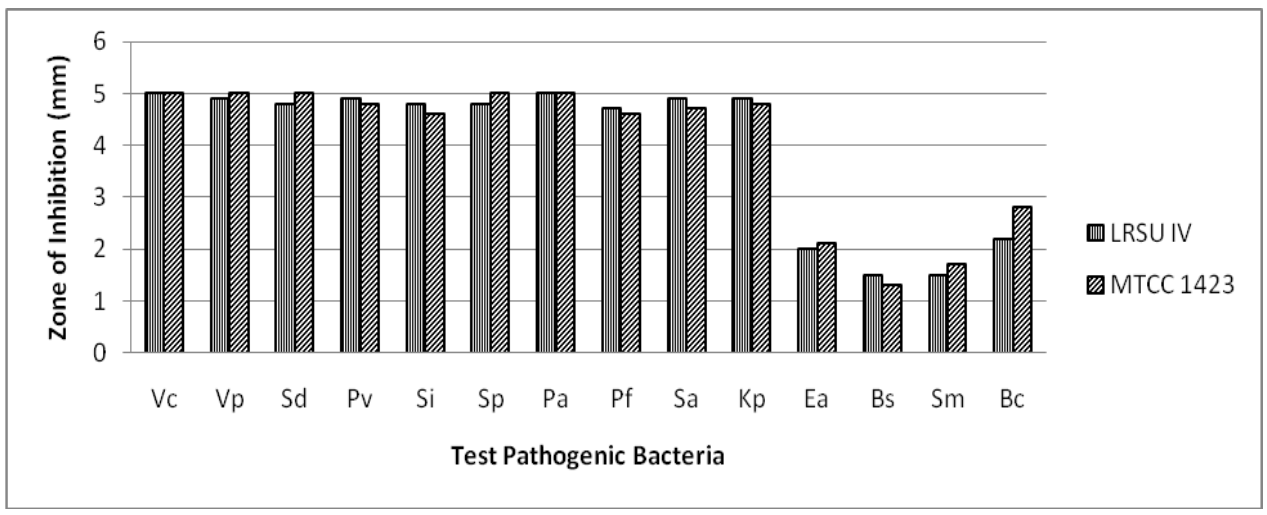

Figure.2 Comparison of Inhibition Pattern of LRSUIV and MTCC 1423 at Different Temperatures

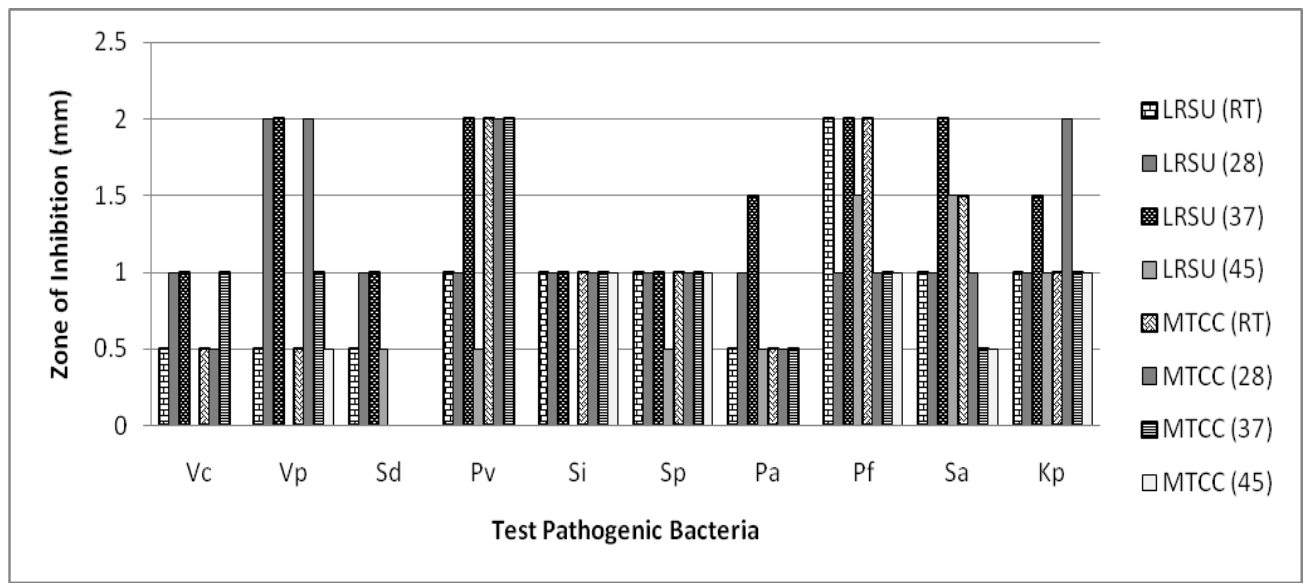

Figure.3 Comparison of Inhibition Pattern of LRSUIV and MTCC 1423 at Different pH

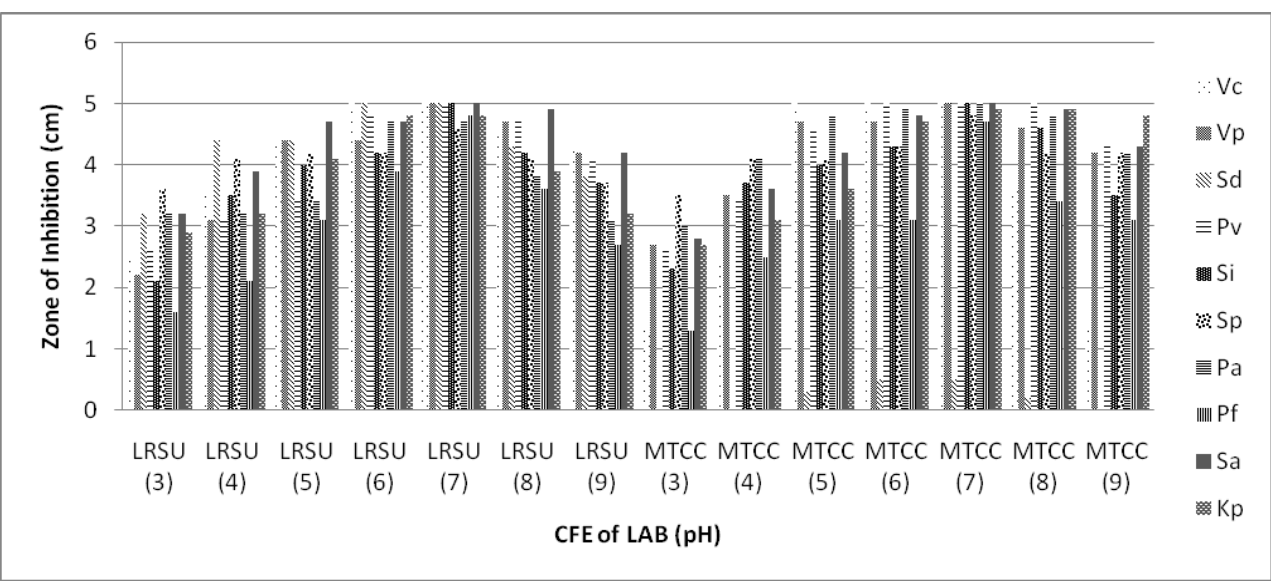


Figure.4 Comparison of Inhibition Pattern of LRSUIV and MTCC 1423 under Different Concentration/Purification Methods

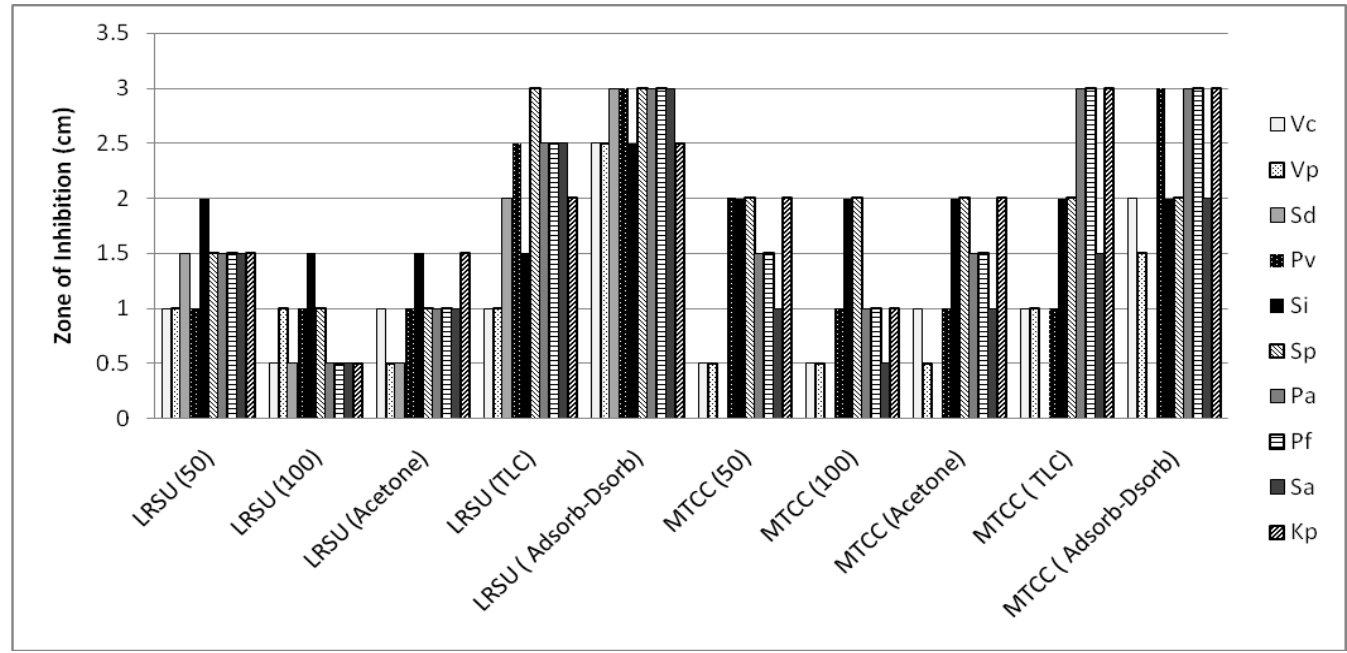

\section{Salt Concentration Assay}

Concentrated CFEs of both LRSU IV and MTCC1423 cultures which were concentrated at $50^{\circ} \mathrm{C}$ and $100^{\circ} \mathrm{C}$ respectively and subjected to zone of inhibition assay; antimicrobial tests showed no major zones of inhibition for most of the test organisms. Thus, the method used was not appropriate in concentrating the bacteriocins produced.

\section{Precipitation Test}

\section{Acetone Precipitation Method}

The bacteriocins did not give significant zones of inhibition (compared with adsorption-desorption or even TLC) when the CFEs of the two probiotic cultures were treated with chilled acetone. Hence, this method of precipitation was also found to be inappropriate as a concentration /purification method.

\section{Adsorption-desorption Method}

The antimicrobial activity of the precipitated bacteriocins showed evident and measurable zones of inhibition in all the pathogens used.
The 48 hours old cultures of MTCC 1423 showed average amount of activity in all the pathogens, but, the old cultures of LRSU IV were seen to have a heightened effect on the three cultures of Proteaus vulgaris, Vibrio parahaemolyticus and Shigella dysenteriae than their MTCC counterparts.

\section{Purification Method}

\section{Thin Layer Chromatography}

In the analytical slides, specific spots were obtained under UV Trans-Illuminator when the first solvent system was used, though; the rate of chromatography was faster in the second system. However, in the preparative slides, the first solvent system was used for better resolution. The spot was eluted with autoclaved distilled water and refrigerated. These samples gave measurable zones of inhibition when subjected to the test pathogens on spread plates.

In conclusion, a bacteriocin producing strain was isolated and the production of bacteriocin was standardized. The bioassay method for the display of its effective antimicrobial effect was also standardized 
and a compared with reported bacteriocin producing strain of Lactobacillus casei. To demonstrate the stability of the bacteriocin the temperature range assay, a $\mathrm{pH}$ range assay was performed to see that the produced bacteriocin was effectively working effectively on its antimicrobial activity under a wide range of temperature and $\mathrm{pH}$. The salt tolerance assay demonstrated that the bacteriocin from LRSU IV had almost no effect at most of the concentrations of the metal salts used in the assay.

On concentrating the bactriocin by heating in a water bath; showed a certain amount of loss of activity in the produced bacteriocin. Acetone precipitated bacteriocin when subjected antimicrobial activity also demonstrated a degree of loss in antimicrobial activity. Although the adsorption-desorption method and the TLC elution ethod demonstrated significant retentivity and stability in the antimicrobial activity.

Thus, from the experiments done, it can be established that the probiotic culture of LRSU IV produces a bacteriocin whose antimicrobial activity and stability is comparably effective against the test potential pathogens.

\section{Acknowledgement}

The work was carried out at the Department of Biotechnology, Haldia Institute of Technology, Haldia. The authors remain thankful for the support provided.

\section{References}

Ahmed, Z., Wang, Y., Cheng, Q., Imran, M. 2010. Lactobacillus acidophilus Bacteriocin, From production to their application: An Overview. Afri. $J$. Biotechnol., 9(20): 2843-2850.

Ali H. Alwan, Ali Haider Alsakini, Fatma Naseer Abdulrassak. 2014. The protective effect of Probiotics (Lactobacillus acidophilus and Saccharomyces boulardii) against infections caused by Staphylococcus aureus In Vitro and In Vivo. Int. J. Curr. Microbiol. App. Sci., 3(7): 886890.

Barefoot, S.F., Klaenhammer, T.R. 1983. Detection And Activity Of Lactacin B, A Bacteriocin produced by Lactobacillus Acidophilus. Appl. Environ. Microbiol., 45(6): 18081815.

Bharal Amit, Sohpal Vipan Kumar. 2013. Evaluation of Antimicrobial Activity of Bacteriocin (L. acidophilus) against human pathogenic and food born microorganisms. Int. J. Innovative Res. Sci. Engi. Technol., 2(9): 42214225.

Brötza, H., Sahlb, H.G. 2000. New insights into the mechanism of action of lantibiotics-diverse biological effects by binding to the same molecular target. J. Antimicrob. Chemother., 46(1): 1-6.

Chakraborty Ankita, Jayati Bhowal. 2015. Isolation, Identification and analysis of Prbiotic properties of Lactobacillus. spp from selected regional dairy product. Int. J. Curr. Microbiol. App. Sci., 4(6): 621-628.

Chandra, S., Chaudhury, U., Banerjee, R. 2010. Development and assessment of a fish feed to assist in aquaculture nutrition management. Researcher, 2(5): 63-75.

Deraz, S.F., Karlsson, E.N., Hedström, M., Andersson, M.M., Mattiasson, B. 2005. Purification and characterisation of acidocin d20079, a bacteriocin produced by lactobacillus acidophilus 
dsm 20079. J. Biotechnol., 117(4): 343-354.

Dhewa Tejpal. 2012. Screening, production purification and potential use of bacteriocins from lactic acid bacteria of meat and dairy food origin. Proceedings of the International Conference on Nutrition and Food Sciences'. IPCBEE. 39: 35-41.

Dieuleveux, V., Van Der Pyl, D., Chataud, J., Gueguen, M. 1998. Purification and characterization of anti-listeria compounds produced by geotrichum candidum. Appl. Environ. Microbiol., 64(2): 800-803.

Ivanova, I., Kabadjova, P., Pantev, A., Danova, S., Dousset, X. 2000. Detection, purification and partial characterization of a novel bacteriocin substance produced by lactoccouslactis subsp. Lactis B14 Isolated From Boza-Bulgarian Traditional Cereal Beverage. Biocatalysis: Fundamentals \& Applications.

Jack, R.W., Tagg, J. R., Ray, B. 1995. Bacteriocins of Gram-Positive Bacteria. Microbiol. Rev., 59(2): 171200.

Kim, S.H., Gilliland, S.E. 1993. Production of bacteriocins by strains of lactobacillus acidophil us from different animal origins. Animal Science Research Report.

Leer, R.J., Jos, M.B., Vossen, M.V.D., Giezen, M.V., Johannes, M.V.N., Pouwels, P.H. 1995. Genetic analysis of acidocin b, a novel bacteriocin produced by lactobacillus acidophilus. Microbiol., 141: 1629-1635.

Mcauliffe, O., Ross, R., Hill, C. 2001. Lantibiotics: Structure, biosynthesis and mode of action. FEMS Microbiol. Rev., 25(3): 285-308.

Muriana, P.M., Klaenhammer, T.R. 1991. Purification and partial characterization of lactacin f, a bacteriocin produced by lactobacillus acidophilus 11088. Appl. Environ. Microbiol., 57(1): 114-121.

Noonpakdee, W., Jumriangrit, P., Wittayakom, K., Zendo, J., Nakayama, J., Sonomoto, K., Panyim, S. 2009. Two-Peptide bacteriocin From Lactobacillus plantarum Pmu 33 strain isolated from som-fak, a thai low salt fermented fish product. Asia Pacific J. Mol. Biol. Biotechnol., 17(1): 19-25.

Ogunbanwo, S.T., Sanni, A.I., Onilude, A.A. 2003. Characterization of bacteriocin produced by lactobacillus plantarum f1 and lactobacillus brevisog1. Afri. J. Biotechnol., 2(8): 219-227.

Okuda, J., Ramamurthy, T., Yamasaki, S. 2007. Antibacterial activity of ciprofloxacin against clinical strains of vibrio cholerae o139 recently isolated from India. Yakugaku Zasshi, 127(5): 903-904.

Pascual, L.M., Daniele, M.B., Giordano, W., Pájaro, M. C., Barberis, I.L. 2008. Purification and partial characterization of novel bacteriocin 123 produced by lactobacillus fermentum 123. Curr. Microbiol., 56(4): 397-402..

Percival, M. 1997. Choosing a probiotic supplement. Advanced Nutrition Publications, Inc. 6(1).

Pingitore, E.V., Salvucci, E., Sesma, F., Nader-Macías, M.E. 2007. Different strategies for purification of antimicrobial peptides from lactic acid bacteria (lab). Communicating Curr. Res. Educational Topics And Trends In Appl. Microbiol.

Rajaram, G., Manivasagan, P., Thilagavathi, B., Saravanakumar, A. 2010. Purification And Characterization Of A bacteriocin produced by 
lactobacillus lactis isolated from marine environment. Adv. J. Food Sci. Technol., 2(2): 138-144.

Riaz, S., Nawaz, S.K., Hasnain, S. 2010. Bacteriocins produced by 1 . fermentum and l.acidophilus can inhibit cephalosporin resistant e.coli. Braz. J. Microbiol. 41: 643-648.

Sankar, N., Ravi, V., DeepthiPriyanka, P., Srinivas Reddy, P., Rajanikanth, V., Kiran Kumar, Indira, M. 2012. Purification and characterization of bacteriocin produced by lactobacillus plantarum isolated from cow milk. Int. J. Microbiol. Res., 3(2): 133-137.

Sanz, Y., Nadal, I., Sanchez, E. 2007. Probiotics as drugs against human gastrointestinal infections. Recent Patents On Anti-Infective Drug Discovery, 2(2): 148-156(9).

Sharma Anayata, Dadhich. 2014. Influence of different prebiotics and probiotics on selective intestinal pathogens. Int. J. Curr. Microbiol. App. Sci., 3(10): 657-663.

Svetlana, L., Šeatović, Jelena, S., JovanovićNovakové, Gordana, N., Zaviśić, Želika, Č. .Radulović, Marija, Đ., Gavrović-Jankulović, Ratko, M.,
Janko. 2011. The partial characterization of the antibacterial peptide bacteriocin $\mathrm{G}_{2}$ produced by the probiotic bacteria Lactobacillus plantarum $\mathrm{G}_{2}$. J. Serb. Chem. Soc., 7(5): 699-707.

Tagg, J.R., Mcgiven, A.R. 1971. Assay system for bacteriocins. Appl. Microbiol., 21(5): 943.

Tulini, F.L., Gomes, B.C., De Martinis, E.C.P. 2011. Partial purification and characterization of a bacteriocin produced by Enterococcus faecium 130 isolated from mozzarella cheese. Clënc. Tecnol. Ailment., Campinas., 31(1): 155-159.

Von Mollendorf, J.W., Todorov, S.D., Dicks, L.M.T. 2009. Optimization of growth medium for production of bacteriocins produced by lactobacillus plantarum jw3bz and jw6bz, and lactobacillus fermentum jw11bz and jw $15 \mathrm{bz}$ isolated from Boza. Trakia $J$. Sci., 7(1): 22-33.

Vuyst, L.D., Leroy, F. 2007. Bacteriocins from lactic acid bacteria: production, purification, and food applications. $J$. Mol. Microbiol. Biotechnol., 13: 194199.

\section{How to cite this article:}

Arikta Biswas and Rajarshi Banerjee. 2016. A Lab Originated Bacteriocin and Its Partial Purification and Demonstration of Antimicrobial Activity. Int.J.Curr.Microbiol.App.Sci. 5(3): 728-737. doi: http://dx.doi.org/10.20546/ijcmas.2016.503.085 